\title{
Sistem Pendukung Keputusan Pemilihan Bibit Tanaman Karet Dengan Metode Profile Matching
}

\author{
Ardin Natalius Harefa ${ }^{1 *}$, Fricles Ariwisanto Sianturi ${ }^{2}$ \\ ${ }^{1,2}$ STMIK Pelita Nusantara \\ J1. Iskandar Muda No. 1 Medan 20154 Indonesia \\ Corresponding author's e-mail: ardinti17@gmail.com
}

\begin{abstract}
Abstrak - PT. Asri Jaya mengalami kesulitan dalam melakukan pemilihan bibit tanaman karet yang terbaik, baik untuk di tanam langsung diperkebunan maupun merekomendasikan untuk dipasarkan kepada perusahanperusahaan perkebunan karet, karena jenis bibit tanaman karet yang ada di perusahaan tersebut memiliki banyak varietas dan beragam serta umur bibit yang berbeda-beda seperti bibit BPM, bibit IRR, IRC, bibit karet kusen, GT (Gondang Tapen), bibit PB (Prang Besar), dan lain sebagainya. Alternatif yang digunakan dalam penelitian ini adalah jenis bibit tanaman karet yaitu bibit BPM (Balai/Pusat Perkebunan Medan, bibit karet IRR (Indonesian Rubber Research), bibit karet IRC (Institute Research of Ceylon), bibit karet kusen, bibit karet GT (Gondang Tapen) dan bibit karet PB (Prang Besar). Kriteria yang digunakan dalam penelitian ini adalah bentuk payung, posisi tangkai daun, bentuk tangkai daun, warna helai daun, bentuk daun, tulang daun, ketebalan daun, tinggi batang, dan umur bibit. Sistem yang dibangun menggunakan bahasa pemograman yang digunakan dalam pembuatan sistem adalah PHP dengan database MySQL. Untuk menghitung nilai total, maka terlebih dahulu harus menentukan persentase core factore dan secondary factore. Pada kasus ini core factor ditentukan dengan nilai persentase sebesar $60 \%$ mengingat faktor utama adalah merupakan aspek atau kriteria yang paling dominan untuk penilaian pemilihan bibit tanaman karet maka persentase nilainya lebih besar dari pada nilai persentase untuk secondary factor yaitu sebesar $40 \%$.
\end{abstract}

Kata kunci: Bibit Karet, Bobot, SPK, Profil Matching, Gap

Abstract - PT. Asri Jaya had difficulty in selecting the best rubber plant seeds, both for direct planting in the plantations and recommending them to be marketed to rubber plantation companies, because the types of rubber plant seeds in the company had many varieties and varied as well as different ages of seeds. -different such as BPM seeds, IRR seeds, IRC, rubber frame seeds, GT (Gondang Tapen), PB seeds (Prang Besar), and so on. The alternatives used in this research are types of rubber plant seeds, namely BPM seeds (Balai/Pusat Perkebunan Medan, IRR (Indonesian Rubber Research) rubber seeds), IRC rubber seeds (Institute Research of Ceylon), frame rubber seeds, GT rubber seeds (Gondang Tapen) and PB (Prang Besar) rubber seedlings. The criteria used in this study were umbrella shape, petiole position, petiole shape, leaf color, leaf shape, leaf bone, leaf thickness, stem height, and seedling age. which is built using the programming language used in making the system is PHP with MySQL database. To calculate the total value, it must first determine the percentage of core factore and secondary factore. In this case the core factore is determined with a percentage value of $60 \%$ considering the main factor is an the most dominant aspect or criteria for assessing the selection of rubber plant seeds, the percentage value is greater than the pe value the percentage for the secondary factor is $40 \%$. Keywords: Rubber Seeds, Weight, SPK, Profile Matching, Gap

\section{Pendahuluan}

PT. Asri Jaya adalah salah satu perusahaan yang bergerak di bidang kontrakator atau leveransir pembibitan tanaman karet dan kelapa sawit berlokasi di Dusun II, Desa Naga Timbul, Kecamatan Tanjung Morawa, Kab. Deli Serdang, Provinsi Sumatera Utara. Perusahaan ini merupakan salah satu perusahaan yang berpengalaman dalam bidang pembukaan lahan, penanaman tanaman perkebunan karet dan sawit, perawatan, pembibitan, dan pemasaran bibit tanaman karet dan kelapa sawit. Bibit tanaman karet merupakan salah satu jenis tanaman perkebunan yang memiliki posisi penting dalam sektor pertanian dan khususnya perkebunan, karena dari sekian banyak tanaman yang menghasilkan getah karet, tanaman karet juga menghasilkan nilai ekonomi yang besar. Para pelanggan yang ingin membeli bibit tanaman karet mengalami kendala dalam melakukan pemilihan bibit tanaman karet yang akan dibeli, karena kurang mengetahui informasi apa saja jenis bibit tanaman karet yang terbaik yang sedang dipasarkan dan tersedia di PT. Asri Jaya. PT. Asri Jaya membutuhkan suatu sistem pendukung keputusan untuk memudahkan dalam pemilihan bibit tanaman karet dengan menggunakan metode profile matching [1].

Sistem pendukung keputusan adalah suatu sistem informasi spesifik yang ditujukan untuk membantu manajemen dalam mengambil keputusan yang berkaitan dengan persoalan yang bersifat semi terstruktur[2]. Sistem ini memiliki fasilitas untuk menghasilkan berbagai alternatif yang secara interaktif digunakan oleh 
pemakai [3]. Untuk mengimplementasikan sistem pendukung keputusan tersebut dalam melakukan pemilihan bibit tanaman karet, maka perlu digunakan metode profile matching. Profile Matching yaitu merupakan proses membandingkan antara kompetensi individu ke dalam kompetensi jabatan sehingga dapat diketahui perbedaan kompetensi [4]. Metode profile matching merupakan salah satu metode yang dapat membantu dalam memaksimalkan hasil pertanian khususnya dalam pemilihan bibit tanaman karet, karena metode ini mengasumsikan bahwa terdapat tingkat variabel prediktor ideal yang harus dipenuhi oleh subjek [5].

Penelitian terdahulu mengenai pemilihan bibit kelapa sawit, dimana dalam penelitian ini menggunakan metode profile matching yang artinya metode ini dapat digunakan untuk menyelesaikan masalah semi terstruktur dengan menghitung konsistensi. Hasil pengujian dari sistem ini memudahkan dalam merekomendasikan bibit kelapa sawit terbaik dengan tingkat akurasi sebesar 95\% [6]. Penelitian mengenai pemilihan varietas jagung berdasarkan kesesuaian lahan. Penelitian ini menggunakan metode profile matching yang dapat memberikan rekomendasi berdasarkan variabel kesesuaian lahan dengan varietas bibit jagung [7]. Berdasarkan pengujian sistem menunjukkan bahwa fitur pada sistem sudah berjalan dengan baik dan layak untuk dijadikan sebagai penunjang keputusan dalam pemilihan varietas jagung dengan tingkat akurasi sebesar 93,33\% [8].

\section{Tinjauan Pustaka}

2.1. Pengambilan Keputusan

Sistem Pendukung Keputusan (SPK) atau Decision Support System (DSS) yaitu merupakan salah satu teknik secara otomatis dalam membuat dan mengambil suatu keputusan[9]. Jika suatu sebuah keputusan dilakukan dengan musyawarah dan memiliki banyak sekali alternatif atau pilihan jawaban tentu akan sangat menguras banyak pikiran dan tenaga serta waktu dan biaya bagi pengambil keputusan untuk memutuskan suatu keputusan dari suatu masalah [10]. Proses pengambilan keputusan dapat dipandang sebagai suatu sistem. Proses pengambilan keputusan yaitu [11]:

1. Masukan (Input)

Masukan dalam proses pengambilan keputusan adalah data dan informasi. Data dapat berupa suatu keadaan, gambar, suara, huruf, angka atau bahasa yang dapat digunakan sebagai bahan untuk melihat lingkungan, objek, kejadian ataupun suatu konsep. Informasi merupakan data yang telah di olah, dapat disajikan dalam bentuk laporan bulanan, laporan triwulan, laporan tahunan ataupun dalam bentuk laporan rekapitulasi.

2. Proses (Process)

Proses pengambilan keputusan merupakan langkah-langkah yang di ambil oleh seorang pengambil keputusan untuk mendapatkan keputusan yang terbaik. Seorang pengambil keputusan tentu saja akan memikirkan secara seksama dan detail tentang keputusan yang akan diambil.

3. Keluaran (Output)

Keluaran dalam proses pengambilan keputusan adalah keputusan yang dipilih oleh seorang pengambil keputusan, dimana keputusan ini tentunya merupakan keputusan terbaik.

2.2. Metode Profile Matching

Kompetensi atau kemampuan tersebut haruslah dapat dipenuhi oleh pemegang atau calon pemegang jabatan. Metode profile matching merupakan salah satu metode yang sederhana dalam sistem pendukung keputusan dengan membandingkan GAP antara nilai alternatif dan kriteria [12]. Langkah-Langkah Metode Profile Matching [13] [14]:

1. Mendefinisikan terlebih dahulu kriteria-kriteria yang dijadikan sebagai tolak ukur penyelesaian masalah.

2. Menghitung nilai GAP antara profil subjek dengan profil-profil yang dibutuhkan menggunakan rumus persamaan:

Gap $=$ Prorfile Subjek - Profile $\mathrm{x}$

Tabel 1. Bobot Nilai Gap

\begin{tabular}{|c|c|l|}
\hline Selisih & Bobot Nilai & \multicolumn{1}{|c|}{ Keterangan } \\
\hline 0 & 6 & Tidak ada GAP (Kompetensi sesuai yang dibutuhkan) \\
\hline 1 & 5.5 & Kompetensi individu kelebihan 1 tingkat/level \\
\hline-1 & 5 & Kompetensi individu kurang 1 tingkat/level \\
\hline 2 & 4.5 & Kompetensi individu kelebihan 2 tingkat/level \\
\hline-2 & 4 & Kompetensi individu kurang 2 tingkat/level \\
\hline 3 & 3.5 & Kompetensi individu kelebihan 3 tingkat/level \\
\hline-3 & 3 & Kompetensi individu kurang 3 tingkat/level \\
\hline 4 & 2.5 & Kompetensi individu kelebihan 4 tingkat/level \\
\hline
\end{tabular}




\begin{tabular}{|c|c|l|}
\hline-4 & 2 & Kompetensi individu kekurangan 4 tingkat/level \\
\hline 5 & 1.5 & Kompetensi individu kelebihan 5 tingkat/level \\
\hline-5 & 1 & Kompetensi individu kurang 5 tingkat/level \\
\hline
\end{tabular}

3. Perhitungan dan pengelompokkan core factor dan secondary factor.

Core Factor merupakan aspek yang paling dibutuhkan oleh jabatan yang diperkirakan dapat menghasilkan kinerja optimal. Sedangkan secondary factor merupakan faktor pendukung core factor.

$$
\mathrm{NCF}=\frac{\sum \mathrm{NC}}{\sum \mathrm{IC}}
$$

4. Perhitungan Nilai Total

Perhitungan nilai total berdasarkan atas persentase dari core factor dan secondary factor yang diperkirakan berpengaruh terhadap aspek penilaian, persamaan untuk mencari nilai total :

$(\mathrm{x}) \% \cdot \mathrm{NCF}+(\mathrm{x}) \% \mathrm{NSF}=\mathrm{N}$

\section{Metode Penelitian}

Adapun tahapan-tahapan dalam penelitian ini sebagai berikut:

1. Indetifikasi Masalah

Identifikasi masalah ini bertujuan untuk mengidentifikasi atau mengenali masalah yang sedang terjadi disekitar, berdasarkan fenomena-fenomena yang terjadi.

2. Pengumpulan Data

Pengumpulan data lakukan dengan melakukan wawancara secara online pada konsultan PT. Asri.

Tabel 2. Kriteria Pemilihan Bibit Tanaman Karet

\begin{tabular}{|l|l|c|}
\hline No & \multicolumn{1}{|c|}{ Kriteria } & Bobot \\
\hline 1 & Bentuk Daun & 5 \\
\hline 2 & Posisi Tangkai Daun & 5 \\
\hline 3 & Bentuk Tangkai Daun & 3 \\
\hline 4 & Warna Helai Daun & 4 \\
\hline 5 & Bentuk Daun & 5 \\
\hline 6 & Tulang Daun & 3 \\
\hline 7 & Ketebalan Daun (mm) & 3 \\
\hline 8 & Tinggi Batang (cm) & 3 \\
\hline 9 & Umur Bibit (Bulan) & 4 \\
\hline
\end{tabular}

Jenis-jenis bibit sebagai alternatif adalah sebagai berikut:

1) Bibit karet BPM (Balai/Pusat Penelitian Perkebunan Medan)

2) Bibit karet IRR (Indonesian Rubber Research)

3) Bibit karet IRC (Institute Research of Ceyclon)

4) Bibit karet kusen

5) Bibit karet GT (Gondang Tapen)

6) Bibit karet PB (Prang Besar)

3. Analisis Data

Proses persiapan pengolahan data dengan menganalisis susunan kriteria-kriteria ke dalam struktur hirarki sesuai dengan skala prioritasnya masing-masing. Dalam proses analisis data ini bertujuan untuk melakukan penyelesaian dan pembahasan dari masalah yang dianalisis.

4. Penerapan Metode

Penerapan metode profile matching untuk kebutuhan sistem yang akan dikembangkan menjelaskan tahap untuk menerapkan metode Profile Matching dalam proses penyelesaian masalah tersebut.

5. Desain dan Perancangan Sistem

Kebutuhan yang digunakan dalam mendesain dan merancang sistem adalah menggunakan UML.

6. Implementasi Sistem

Implementasi sistem ini merupakan suatu langkah yang ditunjukkan untuk diimplementasi dan yang menjadi output dalam penelitian ini yaitu sebuah sistem yang dibangun menggunakan PHP, HTML dan Database $M Y S Q L$.

7. Evaluasi Sistem

Evaluasi sistem ini, bertujuan untuk melakukan evaluasi pada sistem apakah sistem layak atau tidak untuk digunakan dalam pengambilan keputusan pemilihan bibit tanaman karet. 


\section{Hasil dan Pembahasan}

Setelah dilakukan beberapa tahapan analisa data tersebut diatas, maka langkah selanjutnya adalah melakukan pengolahan data tersebut agar dapat diperoleh data yang akan digunakan dalam membangun sistem pendukung keputusan pemilihan bibit tanaman karet dengan menggunakan metode profile matching yaitu sebagai berikut :

1. Jenis Bibit Tanaman Karet

Tabel 3. Data Bibit Tanaman Karet

\begin{tabular}{|c|l|}
\hline No & \multicolumn{1}{|c|}{ Nama Jenis Bibit } \\
\hline 1 & Bibit Karet BPM (Balai/Pusat Penelitian Perkebunan Medan) \\
\hline 2 & Bibit Karet IRR (Indonesian Rubber Research) \\
\hline 3 & Bibit Karet IRC (Intitute Research of Ceylon) \\
\hline 4 & Bibit Karet Kusen \\
\hline 5 & Bibit Karet GT (Gondang Tapen) \\
\hline 6 & Bibit Karet PB (Prang Besar) \\
\hline
\end{tabular}

Sumber : PT. Asri Jaya, Kontraktor (Leveransir) Pembibitan Karet dan Sawit, 2021

1. Aspek/Kriteria Penilaian. Aspek atau Kriteria pemilihan bibit tanaman karet yang digunakan dalam penelitian :

\begin{tabular}{|c|l|l|}
\hline No & Kode & Nama Aspek \\
\hline 1 & K1 & Bentuk Payung \\
\hline 2 & K2 & Posisi Tangkal Daun \\
\hline 3 & K3 & Bentuk Tangkai Daun \\
\hline 4 & K4 & Warna Helai Daun \\
\hline 5 & K5 & Bentuk Daun \\
\hline 6 & K6 & Tulang Daun \\
\hline 7 & K7 & Ketebalan Daun $(\mathrm{mm})$ \\
\hline 8 & K8 & Tinggi Batang (cm) \\
\hline 9 & K9 & Umur Bibit (Bulan) \\
\hline
\end{tabular}

3. Sub-Sub Aspek Penilaian

Menentukan sub kriteria dari setiap kriteria dan bobot yang digunakan untuk memilih bibit tanaman karet tersebut antara lain sebagai berikut:

a. Aspek Bentuk Payung

Bentuk payung pada jenis bibit karet unggul haruslah memiliki kelompok daun termuda.

Tabel 5. Bobot Aspek Bentuk Payung

\begin{tabular}{|c|c|c|c|}
\hline $\begin{array}{c}\text { Sub aspek } \\
\end{array}$ & Kepentingan & Range & Bobot \\
\hline $\begin{array}{l}\text { Memiliki kelompok daun termuda, ukuran, kerapatan dan jarak } \\
\text { antar payung serta membentuk setengah lingkaran }\end{array}$ & Sangat baik & $\%-100 \%$ & 5 \\
\hline Bentuk kerucut, sedang dan terbuka & Baik & $\%-69.9 \%$ & 4 \\
\hline Bentuk busur dan kerucut terpotong, agak bes: & Cukup baik & $\%-44.9 \%$ & 3 \\
\hline
\end{tabular}

b. Aspek Posisi Tangkal Daun

Posisi pangkal daun adalah posisi yang terletak pada bagian paling bawah helaian daun bibit tanaman karet yang terbaik. Posisi tangkal daun yang bagus agak besar dan rata.

Tabel 6. Bobot Aspek Posisi Tangkal Daun

\begin{tabular}{|l|c|c|c|}
\hline \multicolumn{1}{|c|}{ Sub Aspek } & Kepentingan & Range & Bobot \\
\hline Pangkal tangkai daun padat, agak besar dan rata & Sangat Baik & $70 \%-100 \%$ & 5 \\
\hline Pangkal Tangkai Daun kecil, dan bagian atasnya rata & Baik & $45 \%-69.9 \%$ & 4 \\
\hline $\begin{array}{l}\text { Pangkal tangkai daun kecil, jarang dan bagian atasnya } \\
\text { tidak rata }\end{array}$ & Cukup Baik & $15 \%-44.9 \%$ & 3 \\
\hline
\end{tabular}

c. Aspek Bentuk Tangkai Daun 
Bentuk tangkai daun adalah merupakan bagian daun yang mendukung helaiannya dan bertugas untuk menempatkan dan bertugas untuk menempatkan helaian daun pada posisi sedemikian rupa hingga dapat memperoleh cahaya matahari sebanyak-banyaknya.

Tabel 7. Bobot Aspek Bentuk Tangkai Daun

\begin{tabular}{|l|c|c|c|}
\hline \multicolumn{1}{|c|}{ Sub Aspek } & Kepentingan & Range & Bobot \\
\hline Berukuran besar, ukuran panjang dan berbentuk kaki & Sangat Baik & $70 \%-100 \%$ & 5 \\
\hline $\begin{array}{l}\text { Bentuknya agak cembung, panjang, kurus dan arahnya } \\
\text { mendatar }\end{array}$ & Baik & $45 \%-69.9 \%$ & 4 \\
\hline $\begin{array}{l}\text { Bentuknya Lurus hampir berbentuk huruf "S" agak } \\
\text { panjang dan kurus }\end{array}$ & Cukup Baik & $15 \%-44.9 \%$ & 3 \\
\hline
\end{tabular}

d. Aspek Warna Helai Daun

Warna helai daun bibit tanaman karet unggul adalah merupakan suatu organ tumbuhan tanaman karet yang sangat penting yang memiliki warna hijau dan berfungsi untuk menjalankan sintesis senyawa-senyawa organik dengan menggunakan sinar matahari sebagai sumber energi yang diperlukan.

Tabel 8. Bobot Aspek Warna Helai Daun

\begin{tabular}{|l|c|c|c|}
\hline \multicolumn{1}{|c|}{ Sub Aspek } & Kepentingan & Range & Bobot \\
\hline Hijau & Sangat Baik & $70 \%-100 \%$ & 5 \\
\hline Hijau mengkilat & Baik & $45 \%-69.9 \%$ & 4 \\
\hline Hijau ke kuning-kuningan & Cukup Baik & $15 \%-44.9 \%$ & 3 \\
\hline
\end{tabular}

e. Aspek Bentuk Daun

Bentuk daun merupakan salah satu kriteria untuk memilih jenis bibit unggul tanaman karet.

Tabel 9. Bobot Aspek Bentuk Daun

\begin{tabular}{|l|l|l|l|l|}
\hline Sub Kriteria & Gambar & Kepentingan & Range & Bobot \\
\hline Oval & & Sangat Baik & $\begin{array}{r}70 \%- \\
100 \%\end{array}$ & 5 \\
\hline Elips sampai agak oval & & Baik & $45 \%-69.9 \%$ & 4 \\
\hline Elips panjang & & Cukup Baik & $15 \%-44.9 \%$ & 3 \\
\hline
\end{tabular}

\section{f. Aspek Tulang Daun}

Tulang daun merupakan hal yang sangat penting untuk diperhatikan dalam memilih bibit tanaman karet yang terbaik.

Tabel 10. Bobot Aspek Tulang Daun

\begin{tabular}{|l|c|c|c|c|}
\hline \multicolumn{1}{|c|}{ Sub Aspek } & Gambar & Kepentingan & Range & Bobot \\
\hline \multicolumn{2}{|c|}{ Tulang daun menyirip } & Sangat Baik & $70 \%-100 \%$ & 5 \\
\hline Tulang daun menyirip dan kurus & Baik & $45 \%-69.9 \%$ & 4 \\
\hline Tulang daun melintang & Cukup Baik & $15 \%-44.9 \%$ & 3 \\
\hline
\end{tabular}


g. Aspek Ketebalan Daun (mm)

Ketebalan daun bibit tanaman karet sangat diperhatikan dan dijadikan patokan untuk menentukan bibit tanaman karet yang baik dan unggul untuk dibudidayakan atau di tanam di lahan perkebunan.

Tabel 11. Bobot Aspek Ketebalan Daun

\begin{tabular}{|l|c|c|c|}
\hline \multicolumn{1}{|c|}{ Sub Aspek } & Kepentingan & Range & Bobot \\
\hline Ketebalan Daun minimal $0.21-0.24 \mathrm{~mm}$ & Sangat Baik & $70 \%-100 \%$ & 5 \\
\hline Ketebalan Daun minimal 0.15-0.20 mm & Baik & $45 \%-69.9 \%$ & 4 \\
\hline Ketebalan Daun minimal 0.8-0.14 mm & Cukup Baik & $15 \%-44.9 \%$ & 3 \\
\hline
\end{tabular}

h. Aspek Tinggi Batang (cm)

Tinggi batang untuk tanaman karet yang baik adalah merupakan salah satu kriteria untuk pemilihan bibit tanaman karet, karena tinggi batang bibit sangat berpengaruh untuk budidaya tanaman karet sebelum dilakukan penanaman.

Tabel 12. Bobot Aspek Tinggi Batang

\begin{tabular}{|l|c|c|c|}
\hline Sub Aspek & Kepentingan & Range & Bobot \\
\hline $75-100 \mathrm{~cm}$ & Sangat Baik & $70 \%-100 \%$ & 5 \\
\hline $50-70 \mathrm{~cm}$ & Baik & $45 \%-69.9 \%$ & 4 \\
\hline $35-49 \mathrm{~cm}$ & Cukup Baik & $15 \%-44.9 \%$ & 3 \\
\hline
\end{tabular}

i. Aspek Umur Bibit (Bulan)

Umur bibit tanaman karet yang unggul adalah merupakan faktor utama yang perlu dipertimbangkan untuk efisiensi budidaya tanaman karet.

Tabel 13. Bobot Aspek Umur Bibit

\begin{tabular}{|l|c|c|c|}
\hline \multicolumn{1}{|c|}{ Sub Aspek } & Kepentingan & Range & Bobot \\
\hline 15-18 Bulan & Sangat Baik & $70 \%-100 \%$ & 5 \\
\hline 10-14 Bulan & Baik & $45 \%-69.9 \%$ & 4 \\
\hline 5-9 Bulan & Cukup Baik & $15 \%-44.9 \%$ & 3 \\
\hline
\end{tabular}

Dari masing-masing kriteria atau aspek penilaian dalam pemilihan bibit ditentukan bobot setiap kriteria :

a. Mulai dari 70\% s/d 100\% skala bobotnya yaitu 5 (Sangat Baik)

b. Mulai dari $45 \%$ s/d $69.9 \%$ skala bobotnya yaitu 4 (Baik)

c. Mulai dari $15 \%$ s/d $44.9 \%$ skala bobotnya yaitu 3 (Cukup Baik).

Pengelompokkan aspek atau kriteria penilaian dibagi dalam dua kelompok yaitu:

a. Kriteria atau Aspek Utama (core factore)

Faktor utama ( $\mathrm{CF}=$ Core Factore $)$ merupakan faktor yang paling utama menentukan jenis bibit tanaman karet tersebut tergolong dalam bibit terbaik untuk dipilih.

b. Kriteria atau Aspek Pendukung (secondary factore)

Faktor pendukung $(\mathrm{SF}=$ Secondary Factore $)$ merupakan faktor pendukung menentukan jenis bibit tanaman karet tersebut tergolong dalam bibit terbaik untuk dipilih. Nilai profil standar pada aspek penilaian alternatif pada metode profile matching.

Tabel 14. Nilai Pembobotan Profile Standart

\begin{tabular}{|c|c|l|c|c|}
\hline No & Kode & \multicolumn{1}{|c|}{ Kriteria Penilaian } & Range & Bobot Nilai Standar \\
\hline 1 & K1 & Bentuk Payung & $10 \%$ & 5 \\
\hline 2 & K2 & Posisi Tangkal Daun & $10 \%$ & 5 \\
\hline 3 & K3 & Bentuk Tangkai Daun & $10 \%$ & 3 \\
\hline 4 & K4 & Warna Helai Daun & $10 \%$ & 4 \\
\hline 5 & K5 & Bentuk Daun & $10 \%$ & 5 \\
\hline 6 & K6 & Tulang Daun & $10 \%$ & 4 \\
\hline 7 & K7 & Ketebalan Daun (mm) & $10 \%$ & 3 \\
\hline 8 & K8 & Tinggi Batang (cm) & $15 \%$ & 3 \\
\hline 9 & K9 & Umur Bibit (Bulan) & $15 \%$ & 4 \\
\hline
\end{tabular}


Menggolongkan sub kriteria ke dalam faktor utama (core factore) dan faktor pendukung (secondary factore). Berikut ini adalah pengelompokkan sub kriteria penilaian.

Tabel 15. Penggolongan Sub Kriteria

\begin{tabular}{|c|c|c|c|c|c|}
\hline Aspek/Kriteria & Kode & Sub Kriteria & Persen & Bobot & Ket \\
\hline \multirow{3}{*}{ Bentuk Payung } & SA001 & $\begin{array}{l}\text { Memiliki kelompok daun termuda, ukuran, kerapatan dan } \\
\text { jarak antar payung serta membentuk setengah lingkaran }\end{array}$ & 60 & 5 & $\mathrm{CF}$ \\
\hline & SA002 & Bentuk kerucut, sedang dan terbuka & 40 & 4 & SF \\
\hline & SA003 & Bentuk busur dan kerucut terpotong, agak besar dan tertutup & 40 & 3 & SF \\
\hline \multirow{3}{*}{$\begin{array}{l}\text { Bentuk } \\
\text { Tangkal Daun }\end{array}$} & SA004 & Pangkal tangkai daun padat, agak besar dan rata & 60 & 5 & $\mathrm{CF}$ \\
\hline & SA005 & Pangkal Tangkai Daun kecil, dan bagian atasnya rata & 40 & 4 & SF \\
\hline & SA006 & $\begin{array}{l}\text { Pangkal tangkai daun kecil, jarang dan bagian atasnya tidak } \\
\text { rata }\end{array}$ & 60 & 3 & $\mathrm{CF}$ \\
\hline \multirow{3}{*}{$\begin{array}{l}\text { Bentuk } \\
\text { Tangkai Daun }\end{array}$} & SA007 & Berukuran besar, ukuran panjang dan berbentuk kaki & 40 & 5 & $\mathrm{CF}$ \\
\hline & SA008 & $\begin{array}{l}\text { Bentuknya agak cembung, panjang, kurus dan arahnya } \\
\text { mendatar }\end{array}$ & 60 & 4 & $\mathrm{CF}$ \\
\hline & SA009 & $\begin{array}{l}\text { Bentuknya Lurus hampir berbentuk huruf "S" agak panjang } \\
\text { dan kurus }\end{array}$ & 40 & 3 & SF \\
\hline \multirow{3}{*}{$\begin{array}{l}\text { Warna Helai } \\
\text { Daun }\end{array}$} & SA010 & Hijau & 60 & 5 & $\mathrm{CF}$ \\
\hline & SA011 & Hijau Mengkilat & 40 & 4 & SF \\
\hline & SA012 & Hijau ke Kuning-kuningan & 60 & 3 & $\mathrm{CF}$ \\
\hline \multirow{3}{*}{ Bentuk Daun } & SA013 & Oval & 40 & 5 & SF \\
\hline & SA014 & Elips Sampai Agak Oval & 60 & 4 & $\mathrm{CF}$ \\
\hline & SA015 & Elips Panjang & 40 & 3 & SF \\
\hline
\end{tabular}

Tabel 16. Penggolongan Sub Kriteria (Lanjutan)

\begin{tabular}{|c|c|c|c|c|c|}
\hline spek/Kriteria & Kode & Sub Kriteria & Persen & Bobot & Keterangan \\
\hline \multirow{3}{*}{ Tulang Daun } & SA016 & Tulang daun menyirip & 60 & 5 & $\mathrm{CF}$ \\
\hline & SA017 & Tulang daun menyirip dan kurus & 40 & 4 & SF \\
\hline & SA018 & Tulang daun melintang & 60 & 3 & $\mathrm{CF}$ \\
\hline \multirow{3}{*}{$\begin{array}{l}\text { Ketebalan } \\
\text { Daun }(\mathrm{mm})\end{array}$} & SA019 & Ketebalan Daun minimal 0.21-0.24 mm & 60 & 5 & $\mathrm{CF}$ \\
\hline & SA020 & Ketebalan Daun minimal 0.15-0.20 mm & 40 & 4 & SF \\
\hline & SA021 & Ketebalan Daun minimal 0.8-0.14 mm & 40 & 3 & SF \\
\hline \multirow{3}{*}{$\begin{array}{l}\text { Tinggi } \\
\text { Batang }(\mathrm{cm})\end{array}$} & SA022 & $75-100 \mathrm{~cm}$ & 40 & 5 & SF \\
\hline & SA023 & $50-70 \mathrm{~cm}$ & 60 & 4 & $\mathrm{CF}$ \\
\hline & SA024 & $35-49 \mathrm{~cm}$ & 40 & 3 & SF \\
\hline \multirow{3}{*}{$\begin{array}{l}\text { Umur Bibit } \\
\text { (Bulan) }\end{array}$} & SA025 & $15-18$ Bulan & 60 & 5 & $\mathrm{CF}$ \\
\hline & SA026 & 10-14 Bulan & 40 & 4 & SF \\
\hline & SA027 & 5-9 Bulan & 60 & 3 & $\mathrm{CF}$ \\
\hline
\end{tabular}

Langkah selanjutnya setelah diketahui nilai bobot dan pengelompokkan sub kriteria ditentukan nilai GAP alternatif pada setiap kriteria dengan menggunakan nilai profile standart pada setiap alternatif berikut ini:

Tabel 17. Nilai Normalisasi Bobot Pada Setiap Alternatif

\begin{tabular}{|c|c|c|c|c|c|c|c|c|c|c|c|c|c|c|c|c|c|c|c|c|c|c|c|c|c|c|c|}
\hline \multirow[t]{2}{*}{ Alternatif } & \multicolumn{3}{|c|}{$\begin{array}{l}\text { Bentuk } \\
\text { Payung }\end{array}$} & \multicolumn{3}{|c|}{$\begin{array}{c}\text { Posisi } \\
\text { Tangkal } \\
\text { Daun }\end{array}$} & \multicolumn{3}{|c|}{$\begin{array}{c}\text { Bentuk } \\
\text { Tangkai } \\
\text { Daun }\end{array}$} & \multicolumn{3}{|c|}{$\begin{array}{l}\text { Warna } \\
\text { Helai } \\
\text { Daun }\end{array}$} & \multicolumn{3}{|c|}{$\begin{array}{c}\text { Bentuk } \\
\text { Daun }\end{array}$} & \multicolumn{3}{|c|}{$\begin{array}{c}\text { Tulang } \\
\text { Daun }\end{array}$} & \multicolumn{3}{|c|}{$\begin{array}{l}\text { Ketebalan } \\
\text { Daun }\end{array}$} & \multicolumn{3}{|c|}{$\begin{array}{l}\text { Tinggi } \\
\text { Batang }\end{array}$} & \multicolumn{3}{|c|}{$\begin{array}{l}\text { Umur } \\
\text { Bibit }\end{array}$} \\
\hline & $\begin{array}{c}\mathrm{S} \\
01 \\
\end{array}$ & $\begin{array}{c}S \\
02 \\
\end{array}$ & $\begin{array}{c}\mathbf{S} \\
\mathbf{0 3} \\
\end{array}$ & $\begin{array}{c}S \\
04 \\
\end{array}$ & $\begin{array}{c}\mathbf{S} \\
05 \\
\end{array}$ & $\begin{array}{c}S \\
06 \\
\end{array}$ & $\begin{array}{c}\text { S } \\
\mathbf{0 7} \\
\end{array}$ & $\begin{array}{c}\mathbf{S} \\
\mathbf{0 8} \\
\end{array}$ & $\begin{array}{c} \\
09 \\
\end{array}$ & $\begin{array}{c}S \\
10 \\
\end{array}$ & $\mathrm{~S}$ & $\begin{array}{c}S \\
12 \\
\end{array}$ & $\begin{array}{c}S \\
13 \\
\end{array}$ & $\begin{array}{c}S \\
14 \\
\end{array}$ & 15 & $\begin{array}{c}S \\
16 \\
\end{array}$ & $\begin{array}{c}S \\
17 \\
\end{array}$ & $\begin{array}{c}S \\
18 \\
\end{array}$ & $\begin{array}{c}S \\
19 \\
\end{array}$ & $\begin{array}{c} \\
20 \\
\end{array}$ & $\begin{array}{r}S \\
21 \\
\end{array}$ & $\begin{array}{c}S \\
22 \\
\end{array}$ & $\begin{array}{c}S \\
23 \\
\end{array}$ & $\begin{array}{l}5 \\
24 \\
\end{array}$ & $\begin{array}{l}\mathbf{S} \\
25 \\
\end{array}$ & $\begin{array}{c} \\
26 \\
\end{array}$ & $\begin{array}{c}\text { S } \\
27 \\
\end{array}$ \\
\hline A1 & 5 & 4 & 4 & 3 & 3 & 4 & 5 & 5 & 4 & 3 & 4 & 4 & 3 & 5 & 4 & 4 & 5 & 3 & 3 & 5 & 5 & 4 & 4 & 5 & 3 & 4 & 5 \\
\hline A2 & 4 & 4 & 3 & 5 & 3 & 4 & 4 & 4 & 5 & 3 & 5 & 5 & 5 & 4 & 3 & 4 & 4 & 3 & 5 & 3 & 5 & 3 & 4 & 4 & 5 & 3 & 4 \\
\hline A3 & 5 & 4 & 3 & 4 & 4 & 3 & 5 & 5 & 3 & 4 & 3 & 3 & 5 & 4 & 5 & 3 & 4 & 3 & 4 & 4 & 4 & 5 & 4 & 5 & 4 & 3 & 3 \\
\hline A4 & 3 & 3 & 5 & 5 & 5 & 5 & 3 & 3 & 4 & 5 & 4 & 3 & 4 & 3 & 4 & 3 & 4 & 5 & 5 & 4 & 3 & 4 & 5 & 3 & 3 & 5 & 4 \\
\hline A5 & 4 & 5 & 5 & 3 & 4 & 5 & 5 & 4 & 5 & 5 & 5 & 4 & 4 & 3 & 3 & 5 & 3 & 4 & 5 & 3 & 4 & 4 & 3 & 4 & 5 & 4 & 4 \\
\hline A6 & 3 & 4 & 4 & 4 & 5 & 3 & 4 & 3 & 4 & 4 & 4 & 4 & 3 & 5 & 5 & 5 & 5 & 5 & 3 & 5 & 5 & 5 & 5 & 3 & 5 & 5 & 5 \\
\hline
\end{tabular}

Pembobotan Berdasarkan GAP, memberikan bobot untuk masing-masing gap. Hasil dari penilaian gap kemudian dilakukan konversi nilai pembobotan sesuai dengan acuan pembobotan nilai gap pada tabel berikut ini: 
Tabel 18. Acuan Nilai Pembobotan

\begin{tabular}{|c|c|l|}
\hline Selisih & Bobot Nilai & \multicolumn{1}{c|}{ Keterangan } \\
\hline 0 & 6 & Tidak ada GAP (Kompetensi sesuai yang dibutuhkan) \\
\hline 1 & 5.5 & Kompetensi individu kelebihan 1 tingkat/level \\
\hline-1 & 5 & Kompetensi individu kurang 1 tingkat/level \\
\hline 2 & 4.5 & Kompetensi individu kelebihan 2 tingkat/level \\
\hline-2 & 4 & Kompetensi individu kurang 2 tingkat/level \\
\hline 3 & 3.5 & Kompetensi individu kelebihan 3 tingkat/level \\
\hline-3 & 3 & Kompetensi individu kurang 3 tingkat/level \\
\hline 4 & 2.5 & Kompetensi individu kelebihan 4 tingkat/level \\
\hline-4 & 2 & Kompetensi individu kekurangan 4 tingkat/level \\
\hline 5 & 1.5 & Kompetensi individu kelebihan 5 tingkat/level \\
\hline-5 & 1 & Kompetensi individu kurang 5 tingkat/level \\
\hline
\end{tabular}

Pencarian nilai konversi bobot seluruh aspek penilaian selanjutnya. Setelah diketahui nilai dari pada setiap aspek atau kriteria penilaian dalam pemilihan bibit tanaman karet, maka dapat diperoleh nilai dari core factore dan secondary factore setiap sub aspek penilaian pada setiap alternatif.

Tabel 19. Nilai Hasil Akhir

\begin{tabular}{|l|l|l|l|l|l|l|c|c|c|}
\hline $\begin{array}{l}\text { Kod } \\
\mathrm{e}\end{array}$ & $\begin{array}{l}\text { Bentu } \\
\mathrm{k} \\
\text { Payu } \\
\mathrm{ng}\end{array}$ & $\begin{array}{l}\text { Posisi } \\
\text { Tangkal } \\
\text { Daun }\end{array}$ & $\begin{array}{l}\text { Bentuk } \\
\text { Tangkai Daun }\end{array}$ & $\begin{array}{l}\text { Warna Helai } \\
\text { Daun }\end{array}$ & $\begin{array}{l}\text { Bentuk } \\
\text { Daun }\end{array}$ & $\begin{array}{l}\text { Tulang } \\
\text { Daun }\end{array}$ & $\begin{array}{l}\text { Ketebalan } \\
\text { Daun }\end{array}$ & $\begin{array}{l}\text { Tinggi } \\
\text { Batang }\end{array}$ & $\begin{array}{l}\text { Umur } \\
\text { Bibit }\end{array}$ \\
\hline & 10 & 10 & 10 & 10 & 10 & 10 & 10 & 15 & 15 \\
\hline A1 & 5.9 & 5.4 & 5.65 & 5.25 & 5.3 & 5.45 & 4.4 & 5.5 & 5.05 \\
\hline A2 & 5.4 & 6.00 & 5.1 & 4.75 & 5.5 & 5.15 & 5.9 & 5.1 & 6 \\
\hline A3 & 6.0 & 5.15 & 5.85 & 5.3 & 5.2 & 5.3 & 5.3 & 5.2 & 5.3 \\
\hline A4 & 4.3 & 5.35 & 4.9 & 5.45 & 5.5 & 5.5 & 5.7 & 6 & 4.95 \\
\hline A5 & 5 & 5.1 & 4.95 & 5.55 & 5.6 & 4.95 & 6 & 5.5 & 5.85 \\
\hline A6 & 4.7 & 4.85 & 5.2 & 5.55 & 5.1 & 5.35 & 4.4 & 5.7 & 5.35 \\
\hline
\end{tabular}

Hasil akhir dari metode profile matching adalah peringkat atau ranking dari jenis bibit tanaman karet yang akan dipilih. Perhitungan nilai akhir dan perankingan adalah merupakan perhitungan nilai akhir dari semua tahapan.

Tabel 20. Perhitungan Nilai Akhir dan Perankingan

\begin{tabular}{|c|c|c|c|c|c|c|c|c|c|c|c|c|}
\hline kode & $\begin{array}{l}\text { Bentuk } \\
\text { Payung }\end{array}$ & $\begin{array}{c}\text { Posisi } \\
\text { Tangkal } \\
\text { Daun }\end{array}$ & $\begin{array}{c}\text { Bentuk } \\
\text { Tangkai } \\
\text { Daun }\end{array}$ & $\begin{array}{c}\text { Warna } \\
\text { Helai Daun }\end{array}$ & $\begin{array}{l}\text { Bentuk } \\
\text { Daun }\end{array}$ & $\begin{array}{l}\text { Tulang } \\
\text { Daun }\end{array}$ & $\begin{array}{l}\text { Ketebalan } \\
\text { Daun }\end{array}$ & $\begin{array}{l}\text { Tinggi } \\
\text { Batang }\end{array}$ & $\begin{array}{l}\text { Umur } \\
\text { Bibit }\end{array}$ & $\begin{array}{l}\text { NT. } \\
\text { CF }\end{array}$ & NT.SF & TOTAL \\
\hline A1 & 0.59 & 0.54 & 0.565 & 0.525 & 0.53 & 0.545 & 0.44 & $\begin{array}{c}0.36666 \\
6667 \\
\end{array}$ & $\begin{array}{c}0.33666 \\
6667 \\
\end{array}$ & $\begin{array}{c}2.22 \\
5 \\
\end{array}$ & $\begin{array}{l}2.213 \\
3333 \\
\end{array}$ & $\begin{array}{c}4.4383333 \\
333333 \\
\end{array}$ \\
\hline $\mathrm{A} 2$ & 0.54 & 0.6 & 0.51 & 0.475 & 0.55 & 0.515 & 0.59 & 0.34 & 0.4 & 2.2 & 2.32 & 4.52 \\
\hline A3 & 0.6 & 0.515 & 0.585 & 0.53 & 0.52 & 0.53 & 0.53 & $\begin{array}{c}0.34666 \\
6667 \\
\end{array}$ & $\begin{array}{c}0.35333 \\
3333 \\
\end{array}$ & 2.22 & 2.29 & 4.51 \\
\hline A4 & 0.43 & 0.535 & 0.49 & 0.545 & 0.55 & 0.55 & 0.57 & 0.4 & 0.33 & $\begin{array}{c}2.00 \\
5\end{array}$ & 2.395 & 4.40 \\
\hline A5 & 0.5 & 0.505 & 0.495 & 0.555 & 0.56 & 0.495 & 0.6 & $\begin{array}{c}0.36666 \\
6667\end{array}$ & 0.39 & 2.06 & $\begin{array}{c}2.406 \\
6667 \\
\end{array}$ & $\begin{array}{c}4.4666666 \\
666667\end{array}$ \\
\hline A6 & 0.47 & 0.485 & 0.52 & 0.555 & 0.51 & 0.535 & 0.44 & 0.38 & $\begin{array}{c}0.35666 \\
6667 \\
\end{array}$ & $\begin{array}{c}1.98 \\
5 \\
\end{array}$ & $\begin{array}{c}2.266 \\
6667 \\
\end{array}$ & $\begin{array}{c}4.2516666 \\
666667 \\
\end{array}$ \\
\hline Ket & & SF & & CF & SF & \multicolumn{4}{|c|}{$\mathrm{CF}$} & & & \\
\hline
\end{tabular}

Implementasi adalah kegiatan yang dilakukan melalui perencanaan dan mengacu pada aturan tertentu untuk penerapan atau pelaksanaan hasil dari sistem untuk mencapai tujuan kegiatan atau perancangan sistem. Jenis bibit (aternatif) pada sistem pendukung keputusan keputusan pemilihan bibit tanaman karet menggunakan metode profile matching. Tampilan form ini berfungsi untuk menambahkan data jenis bibit (alternatif). 


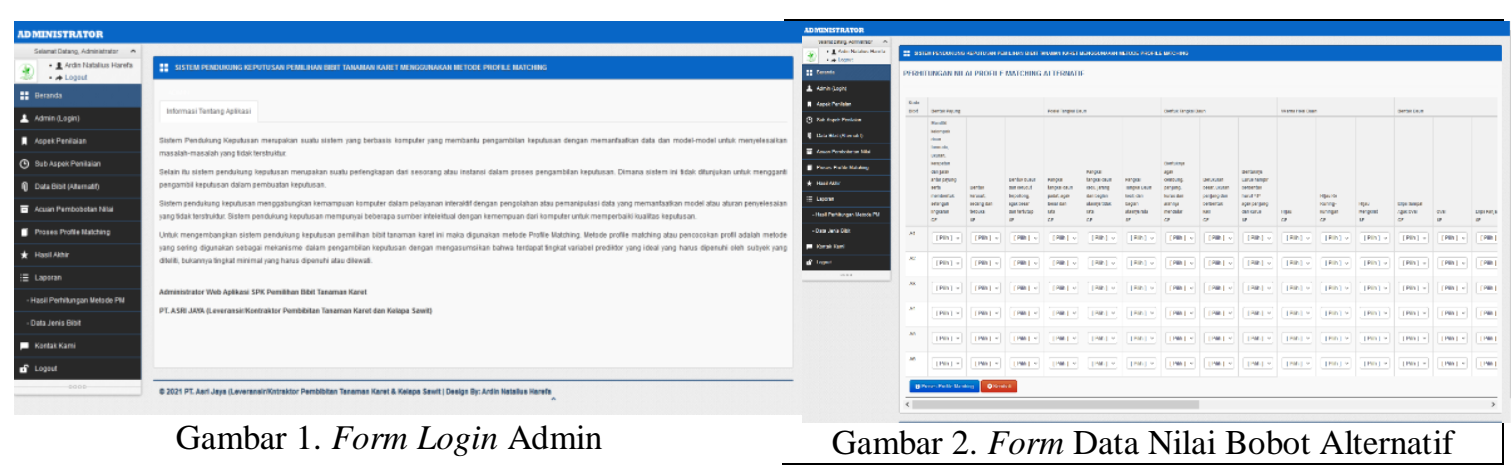

Tampilan impelementasi ini berfungsi untuk menampilkan informasi daftar data acuan bobot nilai alternaitf dalam pemilihan bibit tanaman karet. Form ini hanya bisa di akses di halaman utama admin.

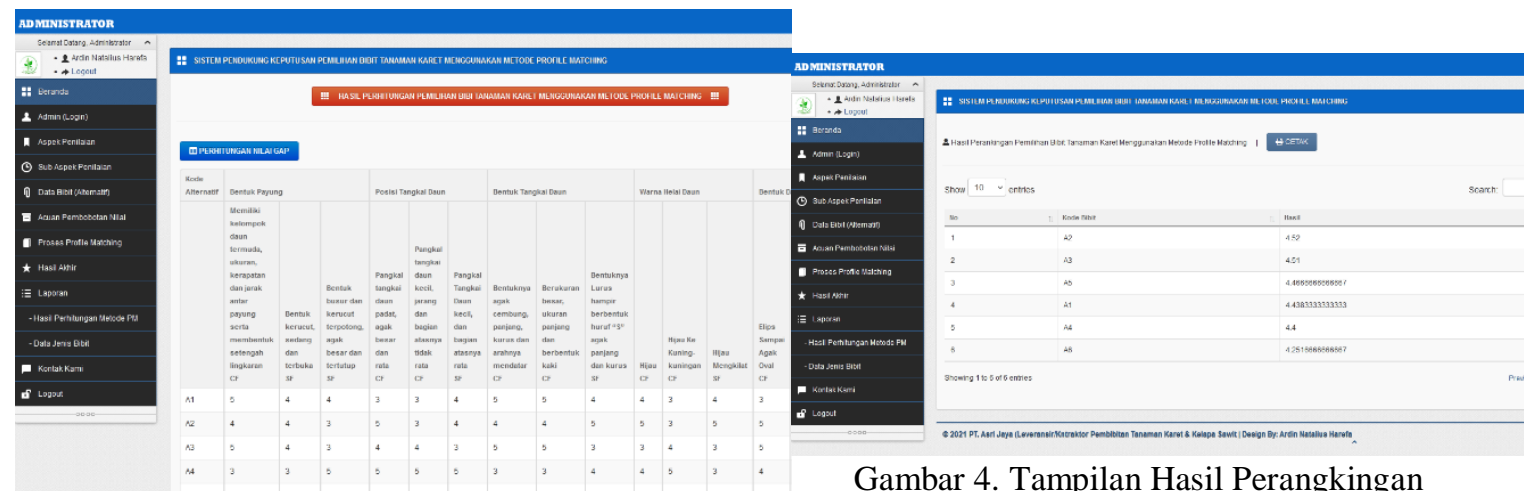

Gambar 3. Tampilan Nilai Akhir

\section{Kesimpulan}

Kesimpulan dari penelitian :

1. Sistem dapat memudahkan PT. Asri Jaya (Leveransir/Kontraktor Pembibitan Tanaman Karet dan Sawit) dalam memilih bibit tanaman karet yang akan dilakukan penjualan atau ditanam langsung di lahan perkebunan karet.

2. Program kerja dari sistem yang dibangun bisa terbilang cepat dibandingkan dengan cara-cara manual.

3. Program mudah diakses oleh pembuat keputusan atau direktur yang ingin menentukan atau memilih bibit tanaman karet yang berkualitas atau terbaik untuk dijual atau ditanam langsung pada lahan perkebunan karet oleh PT. Asri Jaya.

\section{Daftar Pustaka}

[1] A. P. Kusuma, "PROFILE MATCHING DALAM," vol. 13, no. 2, pp. 129-140, 2019.

[2] S. Susmanto, Z. Zulfan, and M. Munawir, "Sistem Penerapan Fuzzy Multi Attribute Decision Making (MADM) Dalam Mendukung Keputusan Untuk Menentukan Lulusan Terbaik Pada Sekolah Tinggi Teknik Poliprofesi Medan,” J. Nas. Komputasi dan Teknol. Inf., vol. 1, no. 1, 2018.

[3] F. Wahyudi, "Sistem Pendukung Keputusan Penentuan Guru Berprestasi Di Sma Negeri 1 Sumberpucung," vol. 1, no. 2, pp. 50-69, 2018.

[4] Z. Efendi, "Sistem Pendukung Keputusan Pemilihan Lokasi Perumahan Menggunakan Metode Profile Matching," JURTEKSI (Jurnal Teknol. dan Sist. Informasi), vol. 6, no. 1, pp. 79-86, 2019.

[5] A. Prasetyo, A. O. Sari, and R. Aprilia, "PENGGUNAAN METODE PROFILE MATCHING DALAM SISTEM PENDUKUNG KEPUTUSAN KENAIKAN JABATAN PADA INSTITUSI BANK (STUDI KASUS PT Bank Negara Indonesia, Persero Tbk - KC PECENONGAN)," J. Teknol. Inform. Komput., vol. 5, no. 1, pp. 96-107, 2019.

[6] A. Arifsyah and A. Sindar, "Sistem Pakar Diagnosa Penyakit Pohon Karet Dengan Metode Certainty Factor," J. Nas. Komputasi dan Teknol. Inf., vol. 2, no. 2, pp. 175-180, 2019.

[7] E. Pawan, A. Jasuma, A. Y. Arif, and K. Kusrini, "Sistem Pendukung Keputusan Menentukan Bibit Padi Terbaik Menggunakan Metode Gap Kompetensi," Sisfotenika, vol. 10, no. 1, p. 24, 2020. 
[8] M. C. Umam, D. Arifianto, and T. A. Cahyanto, "Sistem Pendukung Keputusan Pemilihan Karyawan Berprestasi di Universitas Muhammadiyah Jember Dengan Metode Profile Matching," pp. 57-66, 2018.

[9] Y. Sembiring and P. M. Hasugian, "Sistem Pendukung Keputusan Menentukan Tingkat Resiko Penjualan Online Dengan Menggunakan Metode TOPSIS," J. Nas. Komputasi dan Teknol. Inf., vol. 4, no. 1, pp. $20-25,2021$.

[10] A. C. Mutia, A. F. Sundoro, and A. Yajiddin, "Pada Sistem Pendukung Keputusan Prakiraan Cuaca," vol. 11, no. November, pp. 81-96, 2017.

[11] E. Sutinah, "Sistem Pendukung Keputusan Menggunakan Metode Profile Matching dalam Pemilihan Salesman Terbaik," Informatics Educ. Prof., vol. 2, no. 1, p. 234409, 2017.

[12] A. A. Tri Susilo, "Penerapan Metode Profile Matching Pada Sistem Pendukung Keputusan Pemilihan Ketua Program Studi (STUDI Kasus : Program Studi Teknik Informatika STMIK Musi Rawas)," JUITA J. Inform., vol. 5, no. 2, p. 87, 2018.

[13] R. O. Atik Budi Paryanti, Sumarsid, "JURNAL ILMIAH M-PROGRESS," vol. 11, no. 1, pp. 73-82, 2021.

[14] A. Sindar, R. M. Sinaga, M. Marbun, and A. S. Sitio, "PENGENALAN PEMROGRAMAN WEB PADA KARANG TARUNA PEMUDA PEMUDI SEJATI GUNA MENGEMBANGKAN SKILL,” vol. 5, no. 4, pp. 1631-1639, 2021. 